Ochrony Przyrody [Electronic Resource]. - http://www.ptsop.org.pl 7. Fundacja Nasza Ziemia [Electronic Resource]. - http://naszaziemia.pl/ 8. Парма X. Польща - Марки: Парма Прес - 2011. - 127 c. 9. Wychowalek K., Świderek G., Kto ma czas na ekologię? - Łódź: Źródła, - 2011. 10. Stowarzyszenie Przyjaciół i Sympatyków Ekologii «Zielona Ziemia», Szkolna edukacja ekologiczna - dylematy, Marcin Howaniec, 2009. 11. Lapiński J., Abdurakhmanov G. Rozwój myśli ekologicznej w polsce i w rosji wybrane aspekty, EkoKUL, Lublin, 2005.

УДК 378.147:37.013.42

Ірина Доброскок

\title{
РОЛЬ СОЦІАЛЬНОЇ ПЕДАГОГІКИ У ФОРМУВАННІ ПРОФЕСІЙНОЇ ОСОБИСТОСТІ У ПРОЦЕСІ МАГІСТЕРСЬКОГО НАВЧАННЯ
}

Доброскок I. І. Роль соціальної педагогіки у формуванні професійної особистості у процесі магістерського навчання

У статті розкрито роль соціальної педагогіки у формуванні професійної особистості у процесі магістерського навчання. Обгрунтовано позицію про те, що розвиток соціальної педагогіки сприятиме розвитку соціального педагога як професійної особистості у процесі здійснення соціально-педагогічної діяльності, що надасть можливість досягнути відповідного рівня у підготовці магістрантів вищих навчальних закладів освіти.

Ключові слова: магістри соціальної педагогіки, соціальна педагогіка, соціальний педагог.

Доброскок И. И. Роль социальной педагогики в формировании профессиональной личности в процессе магистерского образования.

В статье раскрывается роль социальной педагогики в формировании профессиональной личности в процессе магистерского образования. Обосновано позицию о том, что развитие социальной педагогики будет способствовать развитию социального педагога как профессиональной личности в процессе осуществления социально-педагогической деятельности, что позволит дистичь необходимого уровня в подготовке магистрантов высших учебных заведений образования.

Ключевые слова: магистры социальной педагогики, социальная педагогика, социальный педагог.

Dobroskok I. I. The role of social pedagogy in the formation of professional identity in the master's of education.

The article revealed the role of social pedagogy in the formation of professional identity in the Master's teaching. Substantiates the view that the development of social pedagogy will be accompanied by the development of social identity as a professional educator in the implementation of social and educational activities that will contribute to the achievement of the respective level of training graduate students of higher educational institutions of education.

Key words: masters of social pedagogy, social preparation, social worker.

Економічний і соціальний розвиток України значною мірою залежить від особистісних і професійних якостей іiі громадян. 3 одного боку, розвиток людини охоплює нові знання, змінюючи реальне життя за рахунок потреб суспільства, що супроводжується тенденціями диференціації та спеціалізації наук, які розвиваються самостійно, $з$ іншого - суміжні й диференціальні науки інтегруються, вивчаючи один об'єкт з різних позицій, що уможливлює створення системи професійної підготовки студентів на тлі практичного людинознавства. Це має виявлятися у зростаючій інтелектуалізації соціальних винників, що впливатимуть на розвиток економіки нашої держави та базуватимуться на глибоких знаннях іiї законів, які конституюються на основі загальнолюдських цінностей. Реалізація законів націлена на визнання гідності й унікальності кожної особистості, вироблення її професійних навичок.

У зв'язку з вищеокресленим важливим завданням вищої освіти $є$ формування у студента гуманістичних нахилів, розвиток комунікативних та організаторських здібностей, умінь аналізувати соціальні явища i процеси, визначати перспективу свого майбутнього в суспільному та професійному житті. 
Нагальною необхідністю сучасної вищої школи є переосмислення всього процесу освіти, іiі мети, основних завдань і принципів; перехід до поєднання наукової і практичної сфер соціальної педагогіки; переосмислення практичної діяльності в підготовці магістрів шляхом самостійного та творчого усвідомлення ними набутих знань (творчо переосмислені знання в процесі культуротворчої діяльності міцні, дієві, а стимулом їх поповнення слугує не оцінка викладача, а практична самооцінка, у тому числі й соціального суб'єкта, який розвивається та формується і стає неповторною особистістю).

Етап становлення наукової школи соціально-педагогічної науки й практичної соціальнопедагогічної діяльності зумовили дискусійний характер питань щодо змісту навчального предмета «Соціальна педагогіка»: змістове навантаження категорій і понять, теоретичних основ дидактичної системи підготовки магістрів соціальної педагогіки тощо.

Перевага традиційних технологій навчання та практики навчання, відсутність орієнтації в підготовці кадрів саме на регіональні потреби, зміна у підходах до освітянського процесу в цілому вимагають переосмислення теоретико-методологічних основ системи професійної підготовки майбутніх соціальних педагогів в умовах магістратури.

Методологічну й теоретичну основу організації навчальної діяльності майбутніх соціальних педагогів становлять теорії соціальних дій (В. Загвязинський, Т. Парсонс, Г. Спенсер та ін,); системного підходу (В. Афанасьєв, В. Беспалько, В. Василькова, Е. Юдін та ін.); концепції відкритих та активних соціально-педагогічних систем (А. Анохін, П. Кліщ, О. Кузьменко, В. Сухомлинський); концепції використання різних технологій у педагогічних процесах (Я. Бурлака, Р. Вайнола, А. Капська, І. Смолюк, С. Холостова та інші).

Аналіз педагогічної і психологічної літератури, детальне вивчення методичних розробок, що складають емпіричний матеріал, дозволяють зробити висновок про недостатньо розроблене системне теоретико-методичне й науково-технологічне забезпечення фахової підготовки майбутніх соціальних педагогів.

Низка заходів, спрямованих на реалізацію положень Болонської декларації в системі вищої освіти, розкриває широкі перспективи для розв'язання окресленої проблеми в умовах магістратури 3 метою усунення суперечності між існуючою в практиці університету усталеною системою фахової підготовки соціального педагога й особистісно орієнтованим характером діяльності соціального педагога, зумовленою цим потребою в переході від інформаційного методу навчання до діяльнішого, функціонально-цільового підходу.

Метою публікації є обгрунтувати й довести ефективність соціально-педагогічних умов (теоретико-методичне й організаційно-технологічне забезпечення навчального процесу) у фаховій підготовці магістрів соціальної педагогіки. Формування професійних знань, умінь і навичок майбутніх фахівців, упровадження в систему професійної підготовки технологій, на нашу думку; має функціональний характер, що нівелює достатній рівень особистісного розвитку студента. В умовах інформаційної доби саморозвиток особистості як у професійній, так і в особистісній сфері значною мірою гальмується, що може призвести до відчуження особистості від суспільства і, як наслідок, зниження ії̈ загального культурного розвитку.

Пропозицією $є$ перехід на розвивальне, професійно орієнтоване навчання, яке дозволить змінити пріоритети розвитку суспільства і визначити вимоги до змісту професійної компетентності студента, який навчається в магістратурі. Компетентність становить інтегрований результат освіти, який дозволяє розв'язувати цілий клас завдань, передбачати мету діяльності та її результат. Поняття компетентності відображає цілісну сутність результату навчання на будь-якому рівні та в будь-якому аспекті.

Професійна компетентність передбачає не лише здійснення на високопрофесійному рівні соціально-педагогічної діяльності, але й бездоганне володіння предметом, що уможливлює вільну орієнтацію в напрямах розвитку соціально-педагогічної науки, тенденцій розвитку наукових шкіл; усвідомлення і виконання своїх зобов'язань перед суспільством; адекватне реагування на різні соціокультурні ситуації та знаходження оптимального варіанта розв'язання.

Ураховуючи зазначене вище, ми у своїй діяльності в межах викладання соціальної педагогіки враховуємо одну із професійних компетентностей - особистісно-індивідуальну, яка стосується до самої людини, її особистості як суб'єкта спілкування між людьми. Наприклад, магістрант володіє предметними знаннями, які свідчать про рівні сформованості професійних умінь і навичок, що характеризують професійний портрет майбутнього соціального педагога, а 
також рівні сформованості якостей студента, що характеризують його як індивідуальну особистість. Уважаємо, що визначальним у системі професійної підготовки майбутніх педагогів має бути особистісно орієнтований підхід, який висуває на перший план особистість, здатну до самовдосконалення, коли в процесі своєї професійної діяльності розкриваються ії інтелектуальні, пізнавальні та креативні здібності, ураховується мотивація поведінки та визначається система цінностей, що дозволяє виконати професійно й ефективно свої обов'язки перед державою та суспільством.

Визначальну роль у формуванні професійної особистості належить соціальним та гуманітарним наукам, в основу яких покладено особистісно-індивідуальні компетентності. На наш погляд, гуманітарна освіта сприяє розвитку особистісної та професійної самореалізації, ураховуючи новітні технології освіти. Студент, який навчається в магістратурі, опанувавши предмет, повинен:

- знати теоретичні основи соціальної педагогіки як науки і практичної діяльності; різноманітні технології соціально-педагогічної діяльності та алгоритми їх ефективного застосування;

- уміти проектувати і здійснювати соціально-педагогічну діяльність у процесі навчання.

Під час навчально-виховного процесу кожний студент має володіти і практичними навичками, які дозволять йому здійснювати діагностування соціальної ситуації, у якій перебуває особистість, проводити аналіз життєвих та освітянських ситуацій розвитку людини та враховувати за необхідності індивідуальну програму соціально-педагогічної діяльності.

В умовах гуманізації навчання кожний магістр має переборювати односторонність власної підготовки, націлюватися не тільки на обсяг наукових знань, але й бути носієм гуманітарної культури. Передусім з витоку своєї професійної діяльності соціальний педагог повинен уміти консультувати та бути фасилітатором під час обговорення на заняттях, засіданнях проблемних груп чи наукових-дослідницьких гуртків певного питання чи проблеми, простежувати, мобілізувати і навіть створювати відповідні суспільні ресурси, тобто бути компетентним у багатьох галузях знань. Професійну компетентність майбутній соціальний педагог має виявляти в таких напрямах діяльності: планування й оцінка ситуацій; прийняття відповідальності за свої професійні дії; вибір оптимального вирішення питання тощо.

Отже, соціальному педагогу необхідні і когнітивні, і міжособистісні навички, а також організаційно-адміністративні здібності. Окрім цього, практика соціального педагога потребує, щоб студент, який навчається на магістерських курсах, не тільки володів знаннями та практичними уміннями, але й був людиною творчою і наполегливою в досягненні своєї мети. Усе це свідчить про міждисциплінарний характер навчання, що дозволяє стверджувати про науку, яка має складатися 3 двох розділів: теоретико-методологічного, фундаментального (методологія, закони, категоріальний апарат) і прикладного (галузь соціально-практичного, управлінського вдосконалення теоретичного й емпіричного, наукове забезпечення вирішення практичних соціальних завдань у суспільстві, які зможе вирішувати соціальний педагог).

Соціальна педагогіка, як і будь-яка інша спеціальність, має свою структуру, яка зумовлює взаємозв'язок усіх елементів навчальної діяльності. В умовах навчання ми можемо виділити структуру професійної особистості під час магістерського курсу, що містить такі компоненти: суб'єкт, об'єкт, мета, функції, методи, форми, засоби, технології тощо.

Розглянемо кожний пропонований нами елемент, який у процесі навчання разом з об'єктом діяльності соціального педагога виступає як цілеспрямований і послідовний у забезпеченні визначеної мети соціально-педагогічний процес.

Метою соціальної педагогіки є створення педагогічних умов та психологічного комфорту в процесі навчання студента у магістратурі. Метою діяльності соціального педагога $є$ створення сприятливих умов для розвитку особистості, іiі фізичного, соціального, духовного та інтелектуального розвитку. 3 урахуванням конкретних проблем, які виникають у навчальних закладах, соціальний педагог може розвивати свою діяльність у тих напрямах, якими володіє майстерно та професійно, з метою вияву соціальних та особистісних проблем в учнів усіх вікових категорій. Безумовно, визначальним суб'єктом соціально-педагогічної діяльності $є$ соціальний педагог, але без участі об'єкта в соціально-педагогічному процесі ефективне розв'язання проблеми та взаємодії на рівні суб'єкт-об'єкт неможливе. Питання про сутність і функціональність об'єкта та суб'єкта соціально-педагогічної діяльності залишається дискусійним у сучасній соціальній педагогіці. На нашу думку, 3 одного боку, об'єктом професійної діяльності соціального педагога може виступати особистість, яка навчається в 
магістратурі, пізнає життєву різнобічну дійсність, а 3 іншого - елементи, які сприяють підвищенню професійної майстерності студента, якими володіє викладач, і різноманітність методів, які слугують для формування даної особистості.

Отже, будь-яка діяльність здійснюється за допомогою засобів - методів, форм і технологій, за допомогою яких досягається мета педагогічної діяльності. Діяльність соціального педагога зумовлює його аналіз і реалізацію відповідних видів діяльності, передбачених даними функціями. Функціями соціально-педагогічної діяльності $\epsilon$ аналітична, дослідницька, прогностична, корекційна, соціально-профілактична тощо, які сприяють саморозвиткові, самопізнанню, самооцінці, самоорганізації та самореалізації студента у процесі соціальнопедагогічної діяльності. У свою чергу важливим критерієм усвідомлення професійного становлення особистості є іiї здатність знаходити особистісний потенціал, який може бути задіяний до професійної діяльності, самостійно проектувати та творити своє життя. Соціальна ситуація упродовж навчання у виші може характеризуватися новими взаємовідносинами магістрів у колективі, який складають соціально незалежні члени; в основу такої соціальної ситуації покладено професійно-пізнавальну діяльність, орієнтовану на одержання конкретної спеціальності. За нашими дослідженнями, професійна особистість усе більше може вдосконалюватися відносно оптимального навчально-виховного процесу, що дозволить у подальшому сформувати нову систему становлення особистості. Зміни, які можуть зумовити нову соціальну ситуацію у процесі навчання, сприятимуть професійній діяльності особистості й характеризуватимуться індивідуальними технологіями виконання навчальних дисциплін.

Психолого-педагогічні дослідження доводять, що становлення професійної зрілості студента в магістратурі пов'язане з особистісною позицією студента, практичною реалізацією його дій і вчинків під час навчання. Зважаючи на рівні соціальної зрілості за В. Радулом [4], у своєму дослідженні під час аналізу практичної діяльності ми враховуємо зміст критеріїв соціальної зрілості особистості студентів, які навчаються в магістратурі. Передусім, це соціальна самореалізація особистості, яка пов'язана 3 соціальною активністю; соціальне самовизначення й самовдосконалення особистості; соціальна практичність і відповідальність; соціальна результативність. Зазначимо, що становлення й розвиток професійної особистості зазнає впливу об'єктивних і суб'єктивних чинників, які впливають на його рівень зрілості в системі навчання магістратури. Окрім цього, наголосимо, що особистість має досягнути професійної компетентності, набувши низки характерних рис, сформувавши систему цінностей, а саме здатність до творчості в роботі, що дозволить студенту досягнути значних успіхів у майбутній професійній діяльності.

До визначальних цінностей майбутнього соціального педагога належать: повага до людини як особистості; почуття соціальної відповідальності щодо виконання своїх професійних обов'язків; визнання набутих цінностей упродовж життя та самовизначення 3 метою удосконалення своєї індивідуальності.

Дослідження I. Беха [1], Н. Кузьміної [2], М. Євтуха [5] та інших свідчать про те, що найбільш успішним у професійному плані розвиток особистості відбувається за умови співвідношення педагогічного процесу із зовнішніми чинниками. До цих чинників належить управлінська діяльність, здійснювана колективом; створення креативного мікроклімату, у якому навчається студент; заохочення за результативність робота та досягнуті результати у процесі діяльності тощо.

Задля реалізації відповідних чинників повинна бути і низка необхідних педагогічних та організаційних умов, відповідно до яких у період навчання в магістратурі оптимально формується відповідна професійна готовність і висока самовизначеність майбутніх соціальних педагогів. Технологічне й дидактичне опрацювання кожної дисципліни передбачає та забезпечує реалізацію ціннісних складників процесу професійної підготовки магістрів. Під час підготовки магістрів соціальної педагогіки система навчального процесу має базуватися на закономірностях педагогічного процесу та створенні оптимальних умов. Наголосимо, що завершення освіти полягає в тому, що на кожному етапі магістерського курсу студент має отримати комплекс необхідних загальнотеоретичних знань, професійних умінь і навичок. Це сприятиме не тільки професійному рівню студентів, але й інтелектуальному розвитку, що буде досягнуто завдяки оновленню стандартів вищої освіти. 
Проблема професійної особистості є однією із проблем, які перебувають у царині педагогіки, психології, соціології, соціальної педагогіки тощо. Окреслена проблема є соціально значущою, оскільки не можна подати вичерпної моделі професійної особистості! Можливим видається виокремлення значимих компонентів, що складають систему цінностей: відповідальність, саморозвиток, творчість мислення, позитивне ставлення до світу тощо, які в процесі подальшої роботи сприятимуть розвитку й соціальній зрілості особистості.

Уважаємо, що розвиток соціальної педагогіки сприятиме розвитку соціального педагога як професійної особистості у процесі здійснення соціально-педагогічної діяльності, що надасть змогу досягнути відповідного рівня у підготовці магістрантів вищих навчальних закладів освіти.

\section{Література}

1. Бех І. Д. Особистістю зорієнтоване виховання : [науково-метод. посіб.] / І. Д. Бех - К. : ЗЗМН, 1998 - 204 с. 2. Кузьмина Н. В. Профессионализм деятельности преподавателя / Н. В. Кузьмина. - М., 1992 - 345 с. 3. Мороз О. Г. Педагогіка і психологія вищої школи:[навч. посіб.] / О. Г. Мороз, О. С. Падалка, В. І. Юрченко. - К., 2003 - 267 с. 4. Радул В. В. Соціально-професійне становлення особистості : [монографія] / за ред. В. В. Радула. - Кіровоград : Імекс ЛТД, 2002 - 263 с. 5. Свтух М. Б Соціальна педагогіка: [підручник] / М. Б. Євтух. - К. : МАУП, 2003. - 232 с.

УДК 37:004

Олександр Дрогайцев

\section{КОМП’ЮТЕРИЗАЦІЯ ЯК СКЛАДНИК ІНФОРМАЦЙННӦ̈ ОСВІТИ}

Дрогайцев О. І. Комп’ютеризація як складник інформаційної освіти.

У статті розглянуто питання актуальності комп'ютеризації навчального процесу у сучасній школі. Комп'ютерна освіта розуміється як динамічний процес, основні тенденції його розвитку пов'язані з розширенням сфери використання комп'ютера в навчально-виховному процесі. Розкрито дидактичні можливості мережі Інтернет.

Ключові слова: інформатизація, комп’ютеризація освіти, навчально-виховний процес.

Дрогайцев О. И. Компьютеризация как составляющая информационного образования.

В статье рассматривается вопрос актуальности компьютеризации учебного процесса в современной школе. Компьютерное образование понимается как динамический процесс, основные тенденции его развития связаны с расширением сферы использования компьютера в учебно-воспитательном процессе. Раскрыты дидактические возможности сети Интернет.

Ключевые слова: информатизация, компьютеризация образования, учебно-воспитательный процесс.

Drogaytsev O. I. Computerization as a component of informational education.

The article considers the issue of computerization of the educational process in modern schooling. Computer education is understood as a dynamic process, the main trends of its development are associated with the expansion of computer usage in the educational process. The didactic possibilities of the Internet are revealed.

Key words: informatization of the studying process, studying process computerization.

Сучасна концепція інформатизації освіти грунтується на працях Б. Алганіна, Б. Кисельова, С. Ландо, І. Орєшкова, Б. Сем'янінова, Д. Черешніна та ін. Нині цією проблемою опікуються такі науковці, як: Н. Абакумова, А. Зав'ялов, В. Каптєлін, О. Матвієнко, І. Новик, І. Роберт, Г. Тамм, О. Тихомиров, О. Смолянінова, С. Янковський. Питання комп’ютерної грамотності, інформаційної культури розв'язуються в роботах В. Бусленко, Є. Вєліхова, А. Єршова, Г. Клейман, В. Монахова, С. Пейперт, Б. Хантер розробляють проблему підготовки сучасних фахівців у царині комп'ютерних та інформаційних технологій; М. Макарова, А. Уваров, В. Шолохович досліджують питання визначення умов ефективного оволодіння мережевими технологіями і телекомунікаціями та їх використання у професійній діяльності та навчанні.

Сучасну школу спрямовано передусім на максимальний розвиток здібностей людини до самореалізації. А це можливо лише за умови створення необхідної організаційної та правової основи для доступу до різних джерел інформації, формування і розвитку в особистості 